\title{
HUBUNGAN ANTARA PARITAS IBU DENGAN KEJADIAN PLASENTA PREVIA DI RUANG KEBIDANAN RSUD DR. H ABDUL MOELOEK PROVINSI LAMPUNG
}

\author{
Ana Mariza ${ }^{1}$, Desi Risna Purnamasari ${ }^{2}$ \\ ${ }^{1}$ Dosen Program Studi Kebidanan Universitas Malahayati \\ Email : anamariza@malahayati.ac.id \\ ${ }^{2}$ Mahasiswa Program Studi Kebidanan Universitas Malahayati \\ Email : desirisna1@gmail.com
}

\section{ABSTRACT :RELATIONSHIP BETWEEN MOTHER'S PARITY AND EVENTS IN THE PLASENTA PREVIA MIDWIFERY HOSPITAL DR. H ABDUL MOELOEK LAMPUNG PROVINCE}

Introduction: According to WHO in 2010 as many as 356,000 women died due to childbirth problems, maternal mortality was caused by several factors, including bleeding, one of the causes was placenta previa. The frequency of placenta previa increases in high parity, old age, uterine defects such as cesarean section, curettage, myomectomy and so on.

Purpose :this study was to determine the relationship between maternal parity and the incidence of placenta previa in the obstetrics room of $\mathrm{Dr}$. H Abdul Moeloek, Lampung Province.

Method : This research was conducted using an analytic design with a cross sectional approach. The population in this study were all mothers giving birth at RSUD Dr. H Abdul Moeloek in 2015, which numbered 1435 people. Samples taken using systematic random sampling of 313 people. The analysis used was univariate analysis, namely by presentation and bivariate by chi squere.

Result : The results obtained from the study of the frequency of mothers who experienced placenta previa were $49(15.7 \%)$ people, the distribution of the frequency of parity at risk in labor was 193 (61.7\%) people, There was a relationship between maternal parity and the incidence of placenta previa based on statistical tests obtained $\mathrm{P}$ value $=0.008$ with the result of the $\mathrm{OR}$ value $=$ 2.786 .

Conclusion : Suggestions from researchers are that the hospital is expected to further improve human resources by holding training or seminars for midwifery room employees, installing placenta previa protocols in the obstetrics room so that they can improve supervision of both the delivery process with placenta previa or the factors that cause placenta previa.

Keyword : Parity, Plasenta Previa

\section{INTISARI : HUBUNGAN ANTARA PARITAS IBU DENGAN KEJADIAN PLASENTA PREVIA DI RUANG KEBIDANAN RSUD DR. H ABDUL MOELOEK PROVINSI LAMPUNG}

Latar Belakang :Menurut WHO pada tahun 2010 sebanyak 356.000 perempuan meninggal akibat masalah persalinan, kematian ibu disebabkan beberapa faktor diantaranya adalah faktor perdarahan, salah satu penyebabnya adalah plasenta 
previa. Frekuensi plasenta previa meningkat pada paritas tinggi, usia lanjut, cacat rahim misalnya bekas bedah sesar, kuretase, miomektomi dan sebagainya. Tujuan: tujuan penelitian ini adalah mengetahui hubungan antara paritas ibu dengan kejadian plasenta previa di ruang kebidanan RSUD Dr. H Abdul Moeloek Provinsi Lampung.

Metode penelitian :Penelitian ini dilakukan dengan menggunakan desain analitik dengan pendekatan cross sectional. Populasi pada penelitian ini adalah seluruh ibu bersalin di RSUD Dr. H Abdul Moeloek pada tahun 2015, yang berjumlah 1435 orang. Sample yang di ambil menggunakan systematic random sampling sejumlah 313 orang. Analisa yang digunakan adalah analisa univariat yaitu secara presentasi dan bivariat secara chi squere.

Hasil : Didapatkan hasil penelitian frekuensi ibu yang mengalami plasenta previa sebanyak $49(15.7 \%)$ orang, Distribusi frekuensi paritas beresiko pada ibu bersalin sebanyak 193 (61.7\%) orang, Terdapat hubungan antara paritas ibu dengan kejadian plasenta previa berdasarkan uji statistik didapat $P$ Value $=$ 0,008 dengan hasil nilai $O R=2.786$.

Kesimpulan : diharapkan rumah sakit lebih meningkatkan SDM dengan diadakannya pelatihan ataupun seminar bagi pegawai ruang kebidanan, memasang protab-protab plasenta previa di ruang kebidanan sehingga dapat meningkatkan pengawasan baik proses persalinan dengan plasenta previa atau faktor-faktor penyebab terjadinya plasenta previa.

Kata Kunci : Paritas, Plasenta Previa

\section{PENDAHULUAN}

Perdarahan obstetri yang terjadi pada kehamilan trimester ketiga dan yang terjadi setelah anak atau plasenta lahir pada umumnya adalah perdarahan yang berat, dan jika tidak mendapat penanganan yang cepat bisa mendapatkan syok yang fatal. Salah satu sebabnya adalah plasenta previa. ( Prawiroharjo, 2010 ). Plasenta previa adalah plasenta yang implantasinya tidak normal ialah rendah sekali hingga menutupi seluruh at2au sebagian ostium internum. Implantasi yang normal ialah pada dinding depan atau dinding belakang rahim di daerah fundus uteri. (Aminin, 2019). Menurut WHO pada tahun 2010 sebanyak 356.000 perempuan meninggal akibat persalinan. Sebanyak 99\% kematian ibu akibat masalah persalinan atau kelahiran terjadi di negara - negara berkembang. Rasio kematian ibu dinegara - negara berkembang merupakan tertinggi dengan 450 /
100.000 kelahiran hidup jika dibandingkan dengan rasio kematian ibu di sembilan negara maju dan 51 negara persemakmuran. Menurut WHO angka kematian ibu (AKI) Ditahun 2011, 81\% di akibatkan karna komlikasi selama kehamilan, persalinan, dan nifas. Bahkan sebagian besar dari kematian ibu disebabkan karna perdarahan, infeksi dan preeklamsia.

Angka kematian ibu (AKI) di indonesia masih jauh dari target yang harus dicapai tahun 2015 sesuai dengan kesepakatan sasaran pembangunan millenium. Surve Demografi Kesehatan Indonesia (SDKI) melaporkan AKI pada tahun 2010 AKI 228/100.000 Kelahiran hidup, pada tahun 2012 AKI mencapai 359/100.000 kelahiran hidup, angka ini masih jauh diatas target AKI untuk MDGs (Millenium Development Goals) Tahun 2015 yang ditetapkan WHO sebesar 102/100.000 kelahiran hidup 
(Departemen Kesehatan RI, 2012). Angka kematian ibu (AKI) di provinsi Lampung mencapai 488 kasus, dengan rincian tahun 2011 sebanyak 152 kasus, 2012 terdapat 178 kasus dan 2013 berjumlah 158 kasus dan Angka Kematian Ibu (AKI) berdasarkan laporan dari Kota Bandar Lampung tahun 2012 sebesar 115,8/100,000 Kelahiran Hidup ( Provinsi Dinkes Lampung, 2014).

Masalah kesehatan dan mortalitas sangat erat hubungannya dengan Angka Kematian Ibu (AKI) atau lebih dikenal dengan istilah Maternal mortality (kematian maternal). Kematian ibu atau kematian maternal adalah kematian seorang ibu sewaktu hamil atau dalam waktu 42 hari setelah berakhirnya kehamilan, tidak bergantung pada tempat atau usia kehamilan.( Prawirohadjo, 2010)

Angka Kematian Ibu (AKI) disebabkan kasus komplikasi obstetrik, seperti kasus berat perdarahan antepartum, (plasenta previa dan solutio plasenta), perdarahan postpartum, Cephalo Pelvic Disproportion (CPD), serta malprensentasi letak janin (Manuaba, 2010).

Adapun penyebab dari tingginya angka kematian ibu di dunia dan indonesia dapat dibagi menjadi kematian langsung dan tidak langsung. Secara global 80\% kematian ibu tergolong kematian ibu langsung. Pola penyebab langsung diantaranya yaitu perdarahan (25\%), (perdarahan pasca persalinan), sepsis (15\%), hipertensi dalam kehamilan (12\%), partes macet $(8 \%)$, komplikasi abortus tidak aman (13\%), dan sebab - sebab lainnya (8\%). Sedangkan penyebab tidak langsung diantaranya, penyakit yang sudah ada atau penyakit yang timbul sewaktu kehamilan, misalnya malaria, anemia, HIV/AIDS dan penyakit kardiovaskular. ( Prawirohardjo, 2010). Perdarahan dapat terjadi sebelum persalinan yaitu perdarahan antepartum (plasenta previa, trauma kelahiran, robekan jalan lahir dan inversi uteri. (Prawiroharjo, 2015).

Diantara penyebab perdarahan berkotribusi sekitar 28\% kematian ibu solusio plasenta serta abortus). Selain itu perdarahan dapat terjadi sesudah persalinan yaitu perdarahan post patum seperti retensio plasenta, atonia uteri,

(Imron, 2016). Sedangkan perdarahan dengan kejadian plasenta previa memberi kontribusi sekiatar 0,4\% - 0,6\% dari keseluruhan persalinan dengan penatalaksanan yang baik, mortalitas 50/1000 kelahiran hidup (Rukiyah, 2012)

Penyebab plasenta previa belum diketahui secara pasti, namun ada beberapa faktor yang meningkat terjadinya plasenta previa yaitu paritas tinggi, usia lanjut, cacat rahim, misalnya bekas bedah sesar dankuretase. (Prawirohardjo, 2010) Wanita pada umur kurang dari 20 tahun mempunyai resiko lebih tinggi untuk mengalami plasenta previa karna endrometrium masih belum matang, dan kejadian plasenta previa juga sering terjadi pada ibu yang berumur di atas 35 tahun karena endometrium yang sudah tidak subur. (Nugroho, 2012).

Plasenta previa lebih banyak pada kehamilan dengan paritas tinggi dan pada usia diatas 30 tahun. Juga sering terjadi pada kehamilan ganda dari pada kehamilan tunggal, uterus bercacat ikut mempertinggi angka kejadian plasenta previa.(Prawiroharjo,2010). Pada umumnya gejala pada plasenta previa berlangsung berlahan di awali dengan gejala dini berupa 
perdarahan berulang yang mulanya tidak banyak tanpa disertai rasa nyeri dan terjadi pada waktu yang tidak tertentu, tanpa trauma sehingga antisipasi dalam perawatan prenatal sangat mungkin. (Manuaba 2012).

Berdasarkan hasil pra survey yang dilakukan penulisan pada 11 februari 2016 di dapat data dari bulan Januari - Desember 2015 di RSUD Dr. H. Abdoel Moeloek Propinsi Lampung, dari 1435 ibu bersalin terhadap 144 $(10,0 \%)$ ibu yang mengalami kejadian plasenta previa. Kejadian plasenta previa sendiri mengalami peningkatan dibandingkan tahun 2014 yaitu 125 kasus plasenta previa (Rekam Medik RSUD dr.H. Abduel Moeloek tahun 2015).

Bedasarkan uraian di atas, maka penulis tertarik untuk melakukan penelitian dengan judul " Hubungan antara riwayat kuretase dan paritas ibu dengan kejadian plasenta previa di RSUD Dr. H. Abdoel Moeloek Propinsi Lampung tahun 2015?'”

\section{METODOLOGI PENELITIAN}

Penelitian ini menggunakan jenis penelitian kuantitatif. Rancangan penelitian yaitu desain analitik dengan pendekatan cross sectional.(Notoadmojo, 2012). Populasi pada penelitian ini adalah seluruh ibu bersalin di RSUD Dr. H
Abdul Moeloek pada tahun 2015, yang berjumlah 1435 orang. Sample yang di ambil menggunakan systematic random sampling sejumlah 313 orang. Variabel yang diteliti dalam penelitian ini adalah paritas sebagai variabel independen dan kejadian plasenta previa sebagai variabel dependen. Data yang diambil adalah data sekunder di ruang rekam medis RSUD.DR.H. Abdoel Moeloek. Instrument penelitian menggunakan lembar ceklis yang berisi inisial responden, paritas dan kejadian plasenta previa. Selanjutnya data yang telah dikumpulkan dianalisa secara univariat dan bivariat secara chi squere.

\section{HASIL PENELITIAN \\ Analisa Univariat}

Analisa yang digunakan dalam penelitian ini adalah analisa univariat yang dilakukan pada tia variabel. Hasil dari variabel ini ditampilkan dalam bentuk tabel frekuensi kejadian plasenta previa,distribusi frekuensi paritas ibu bersalin, di Rumah Sakit Dr. H. Abdul Moeloek tahun 2015.

\section{Kejadian Plasenta Previa \\ Berdasarkan data ibu bersalin di RSUD Dr. H. Abdul Moeloek tahun 2015 didapatkan data sebagai berikut :}

Tabel 1.

Distribusi frekuensi paritas dan kejadian plasenta previa 
di RSUD Dr. H. Abdul Moeloek Provinsi Lampung

\begin{tabular}{llll}
\hline No & Variabel & Frekuensi & $\begin{array}{l}\text { Presentase } \\
(\mathbf{1 0 0 \% )}\end{array}$ \\
\hline 1 & Paritas & & \\
& Berisiko & 193 & 61.7 \\
& Tidak Berisiko & 120 & 38.3 \\
2 & Plasenta Previa & & \\
& Plasenta Previa & 49 & 15.7 \\
& Tidak Plasenta Previa & 264 & 84.3 \\
& Total & 313 & 100 \\
\hline
\end{tabular}

Berdasarkan tabel 1 diketahui dari seluruh ibu yang bersalin yaitu diketahui dari seluruh ibu yang bersalin yaitu sebanyak 313 orang. Jumlah ibu beresiko sebanyak 193 orang $(61,7 \%)$ sedangkan jumlah ibu tidak beresiko sebanyak 120 orang

\section{Analisa Bivariat}

Setelah didapatkan data distribusi pada variabel indevendent dan variabel devendent, selanjutnya dilakukan pengujian hipotesis dengan menggunakan analisis bivariat. Analisis ini digunakan untuk
(38,3\%). Sedangkan jumlah ibu yang mengalami plasenta previa sebanyak 49 kasus $(15,7 \%)$, sedangkan yang tidak mengalami plasenta previa yaitu sebanyak 264 kasus $(84,3 \%)$.

mengetahui hubungan antara dua variabel. Analisi bivariat ini diuji dengan menggunkan Chi-Square. Adapun hasil penguji hipotesa dapat dilihat dari uraian dibawah ini :

Tabel 2

Hubungan antara paritas ibu dengan kejadian plasenta previa RSUD Dr. H. Abdul Moeloek Provinsi Lampung

\begin{tabular}{|c|c|c|c|c|c|c|c|c|}
\hline \multirow{3}{*}{ Paritas } & \multicolumn{4}{|c|}{ Kejadian plasenta previa } & & & \multirow{3}{*}{$\begin{array}{c}\mathbf{P} \\
\text { Value }\end{array}$} & \multirow{3}{*}{ OR } \\
\hline & \multicolumn{2}{|c|}{$\begin{array}{l}\text { Plasenta } \\
\text { previa }\end{array}$} & \multicolumn{2}{|c|}{$\begin{array}{c}\text { Tidak } \\
\text { plasenta } \\
\text { previa }\end{array}$} & \multicolumn{2}{|c|}{ Total } & & \\
\hline & $\mathrm{n}$ & $\%$ & $\mathrm{~N}$ & $\%$ & $\mathbf{N}$ & $\%$ & & \\
\hline Beresiko & 39 & 20,2 & 154 & $\begin{array}{l}79 \\
8\end{array}$ & 193 & $\begin{array}{l}10 \\
0\end{array}$ & & \\
\hline $\begin{array}{l}\text { Tidak } \\
\text { beresiko }\end{array}$ & 10 & 8.3 & 110 & $\begin{array}{l}91 . \\
7\end{array}$ & 120 & $\begin{array}{l}10 \\
0\end{array}$ & 0,008 & $\begin{array}{c}2.18 \\
6\end{array}$ \\
\hline Total & 49 & 15,7 & 264 & $\begin{array}{l}84 . \\
3\end{array}$ & 313 & $\begin{array}{l}10 \\
0\end{array}$ & & \\
\hline
\end{tabular}

Berdasarkan data di atas diketahui bahwa dari 193 ibu bersalin yang paritasnya beresiko, sebanyak 39 orang (20.2\%) mengalami plasenta previa dan sebanyak 154 orang $(79.8$ $\%)$ tidak mengalami plaenta previa.
Sebanyak dari 120 ibu bersalin yang paritasnya tidak beresiko sebanyak 10 orang $(8.3 \%)$ yang mengalami plasenta previa dan sebanyak 110 orang ( $91.7 \%$ ) tidak mengalami plasenta previa. Hasil uji statistik 
didapat $P$ Value $=0,008$ artinya terdapat hubungan antara paritas dengan kejadian plasenta previa, dengan $\mathrm{OR}=2.786$ yang berarti wanita denganparitas tinggi beresiko memiliki resiko 2.786 kali lebih tinggi mengalami plasenta previa dibandingkan dengan wanita dengan paritas tidak beresiko.

\section{PEMBAHASAN}

\section{Distribusi frekuensi kejadian plasenta previa}

Berdasarkan tabel 4.3 diketahui dari seluruh ibu bersalin di RSUD Dr. H Abdul Moeloek tahun 2015 yaitu 313 orang, jumlah ibu mengalami plasenta previa sebanyak 49 kasus (15.7\%).

Plasenta previa adalah plasenta yang implantasinya tidak normal, ialaj rendah sekali sehingga menutupi jalan seluruh atau sebagian ostium internum. Implantasi normal adalah pada dinding depan atau dinding belakang rahim didaerah fundus uteri (Taufan, 2012). Plasenta previa disebabkan oleh paritas tinggi, usia lanjut, cacat rahim misalnya bekas bedah sesar, kuretase, miomektomi.

Hasil penelitian ini sejalan degan penelitian yang dilakukan oleh Sugiarto dengan judul "Gambaran plasenta previa di RSUD Tentriawaru Kelas B Kab. Bone periode tahun 2010" Hasil penelitian ini didapatkan kasus plasenta previa menurut faktor umur terbanyak yaitu antara 20-25 tahun sebanya 25 kasus $(62,5 \%)$, kejadian plasenta previa terbanyak menurut paritas yaitu pada paritas 1 sebanyak 10 kasus (25\%) dengan jarak kehamilan 0-2 tahun. Dari hasil penelitian ini disimpulkan bahwa faktor umur, paritas, dan jarak kehamilan berperan untuk terjadinya plasenta previa sehingga di anjurkan untuk melakukan pemeriksaan antenatal secara teratur dan mengikuti program KB.
Menurut penelitian angka kejadian plasenta previa di RSUD Dr. H Abdul Moeloek cukup tinggi, berdasarkan penelitian yang dilakukan didapatkan hasil angka kejadian plasenta previa pada tahun 2015 sebanyak 49 kasus. Hal ini mungkin karena RSUD Dr. H. Abdul Moeloek merupakan rumah sakit rujukan di Provinsi Lampung sehingga jumlah ibu bersalin beresiko tinggi terutama kejadian plasenta previa di RSUD Dr. $\mathrm{H}$. Abdul Moeloek cukup tinggi.

Upaya yang dapat dilakukan untuk mencegah terjadinya peningkatan kejadian plasenta previa adalah dengan menganjurkan para wanita untuk berkonsultasi pada bidan tentang kesehatan reproduksi sehat selain itu menganjurkan ibu hamil untuk rutin memeriksakan kehamilannya dan menganjurkan ibu untuk melalukan pemeriksaan USG sehingga apabila terjadi plasenta previa dapat diketahui sejak dini sebelum menimbulkan perdarahan. Karena apabila terjadi perdarahan dapat terjadi syok bahkan kejang.

\section{Distribusi frekuensi paritas pada ibu bersalin}

Berdasarkan table 4.2.1.3 diketahui dari seluruh ibu yang bersalin yaitu sebanyak 193 orang $(61.7 \%)$ dengan paritas yang tidak beresiko yaitu $<3$ dan 120 orang (38.3\%) beresiko jika paritas > 3. Hal ini menunjukan bahwa sebagian besar paritas responden beresiko multipara dan grandemultioara.

Paritas adalah keadaan wanita sehubungan dengan kelahiran anak yang bisa hidup. Paritas juga menujukan kehamilan terdahulu (Oxorn, 2010). Menurut Rostam (2012) Paritas dibagi menjadi primipara yaitu wanita yang pernah melahirkan sebanyak satu kali. Multipara yaitu wanita yang telah 
pernah melahirkan anak hidup beberapa kali, dimana persalinan tersebut tidak lebih dari lima kali. Grandemultipara yaitu wanita yang telah melahirkan janin aterm lebih dari lima kali.

Hasil penelitian ini sejalan dengan penelitian yang dilakukan oleh Abdat (2010) di rumah sakit Dr. Moewardi Surakarta dengan judul penelitian "Hubungan antara paritas ibu dengan kejadian plasenta previa di rumah sakit Dr. Moewardi Surakarta", didapat hasil penelitian bahwa di RSUD Dr. Moewardi Surakarta pada bulan Januari sampai Desember 2009 terdapat 78 (5,3\%) kasus plasenta previa dari 1457 persalinan. Dalam penelitian ini didapatkan hasil bahwa wanita multipara memiliki resiko 2,53 kali lebih besar untuk mengalami plasenta previa dari pada plasenta primipara.

Jumlah ibu bersalin dengan paritas beresiko di RSUD Dr. H. Abdul Moeloek cukup tinggi yaitu 193 (61.7 $\%$ ) orang dari 313 ibu bersalin. Menurut peneliti hal ini mungkin dikarenakan wanita multipara dan grandemultipara lebih sering mengalami komplikasi selama kehamilan, sehingga pada saat persalinan ibu harus dirujuk dan bersalin drumah sakit sehingga menyebabkan tingginya jumlah ibu bersalin dengan paritas beresiko di RSUD Dr. H. Abdul Moeloek Provinsi Lampung.

Upaya yang dapat dilakukan untuk mencegah terjadinya peningkatan jumlah ibu bersalin dengan paritas beresiko adalah dengan memberikan penyuluhan tentang pentingnya penggunaan kontrasepsi, karena semakin banyak anak yang memiliki akan semakin meningkatnya persalinan dengan resiko tinggi pada ibu.
Hubungan antara paritas dengan kejadian plasenta previa

Berdasarkan hasil penelitian pada tabel 4.2 terjadinya plasenta previa di RSUD Dr. H. Abdul Moeloek Provinsi Lampung tahub 2015 hasil uji statistik didapat $P$ Value $=0,008$ $(P$ Value $<0,05)$ artinya terdapat hubungan antara paritas dengan kejadian plasenta previa. Didapat $\mathrm{OR}=2.786$ yang berarti wanita paritas beresik 2.786 kali lebih tinggi mengalami plasenta previa dibandingkan dengan wanita dengan paritas tidak beresiko.

Pada paritas yang tinggi kejadian plasenta previa makin besar, karena disebabkan oleh vaskularisasi yang berkurang dan perubahan atrofi pada desidua akibat persalinan lampau. Aliran darah ke plasenta tidak cukup dan memperluas permukaannya sehingga menutupi pembukaan jalan lahir. Pada keadaan normal plasenta perimplantasi didaerah corvus uteri pada kehamilan berikutnya didaerah corvus uteri mengalami penurunan fungsi. Hal ini dikarenakan terjadinya degenerasi pada bekar luka implantasi plasenta sewaktu kehamilan sebelumnya sehinga plasenta mencari tempat implantasi yang yang lebih subur (Manuaba. 2012).

Berdasarkan hasil penelitian Abdat (2010) dalam penelitian ini didapatkan hasil bahwa wanita multipara memiliki resiko 2,53 kali lebih besar untuk mengalami plasenta previa dari pada wanita primipara pada penelitian Wardana dan Karkata resiko plasenta previa pada multigravida 1,3 kali lebih besar dibandingkan primigravida. Meningkatkan paritas ibu dengan kejadian plasenta previa disebabkan vaskularisasi yang berkurang dan perubahan atrofi pada desidua akibat persalinan masa lampau. 
Aliran darah ke plasenta tidak cukup memperluas permukaannya sehingga menutupi pembukaan jalan lahir (Sumapraja dan Rachimhadi 2005).

Berdasarkan uraian diatas menurut penelitian wanita paritas tinggi memiliki resiko lebih besar mengalami plasenta previa. Dari total 180 responden yang paritasnya beresiko terdapat 32 orang $(17,8 \%)$ mengalami kejadian plasenta previa dan $148(82,2 \%)$ tidak mengalami plasenta previa dan 109 (94,8\%) tidak mengalami plasenta previa. Hal ini dikarenakan terjadinya degenerasi pada bekas luka implantasi yang lebih subur.

Upaya yang dapat dilakukan untuk mencegah terjadinya plasenta previa pada ibu dengan paritas beresiko adalah dengan memberika promosi kesehatan mengenai hubungan paritas beresiko yaitu paritas lebih dari tiga dengan komplikasi yang mungkin akan terjadi saat kehamilan bahkan persalinan kejadian plasenta previa.

\section{Keterbatasan Penelitian}

Dalam penelitian ini masih banyak terdapat kekurangan dan keterbatasan diantaranya :

1. Desain peneliti menggunakan pendekatan crossectional, dimana desain ini memiliki kelemahan, diantaranya sulit menentukan sebab akibat, dibutuhkan subjek yang cukup banyak terutama jika variabel yang dipelajari banyak dan tidak menggambarkan perjalanan penyakit, insiden maupun prognosis

2. Tidak semua faktor yang berhubungan dengan kejadian plasenta previa diteliti, karena keterbatasan kemampuan, pengetahuan, dan biaya penelitian. Dari banyak faktor yang berhubungan dengan kejadian plasenta previa, penelitian ini hanya memiliki faktor paritas ibu.

\section{KESIMPULAN}

Berdasarkan hasil penelitian dan pembahasan maka dapat di ambil kesimpulan sebagai berikut :

1. Distribusi frekuensi plasenta previa sebanyak $49(15.7 \%)$ orang

2.Distribusi frekuensi paritas beresiko pada ibu bersalin sebanyak 193 (61.7\%) orang

3. Terdapat hubungan antara paritas ibu dengan kejadian plasenta previa berdasarkan uji statistik didapat $P$ Value $=0,008$ dengan hasil nilai $O R=2.786$

\section{SARAN}

Diharapkan dapat menjadi bahan evaluasi tenaga kesehatan dan pertimbangan dalam melaksanakan asuhan kebidanan dengan kejadian plasenta previa dalam meningkatkan standar pelayanan di RSUD Dr. H. Abdul Moeloek. Selain itu dapat dilakukan promosi kesehatan mengenai hubungan antara paritas ibu dengan kejadian plasenta previa.

\section{DAFTAR PUSTAKA}

Abdat, A. U. (2010). Hubungan antara paritas ibu dengan kejadian plasenta previa di Rumah Sakit Dr. Moewardi Surakarta.

$\begin{array}{cr}\text { Aminin, F. (2019). } & \text { Panduan } \\ \text { Praktikum } & \text { Asuhan } \\ \text { Kebidanan: Patologi. } & \end{array}$ Depkes, R. I. (2013). Survei Demografi dan Kesehatan Indonesia Tahun (SDKI) 2012. 
Depkes, R. I. (2010). Survey Demografi dan Kesehatan Indonesia (SDKI) 2012 AKI.

Depkes, R. I. (2012). Survey Demografi Kesehatan Indonesia 2012. Depkes Tahun Jakarta.(2013). RI: Kesehatan Indonesia. Profil

Fitria, L. (2014). Hubungan Paritas dengan Kejadian Plasenta Previa. Oksitosin: Jurnal Ilmiah Kebidanan, 1(2), 6773.

Imron, R., Asih, Y., \& Indrasari, N. (2016). Buku Ajar Asuhan Kebidanan Patologi dalam Kehamilan, Persalinan, Nifas dan Gangguan Reproduksi.

Lampung, D. P. (2015). Profil Kesehatan Provinsi Lampung Tahun 2014. Bandar Lampung.

Lestari, I. M., \& Misbah, N. (2015). Hubungan Antara Paritas Dan Umur Ibu Dengan Kejadian Plasenta Previa. Jurnal Obstretika Scientia, 2(2), 122-140.

Mochtar, R. (2012). Sinopsis Obstetric Fisiologi dan Patologi jilid 1. Jakarta: Penerbit buku kedokteran EGC.

Manuaba, I. B. G. (2010). Ilmu kebidanan, penyakit kandungan dan keluarga berencana. Jakarta:

Notoatmodjo, S. (2012). Metodologi penelitian kesehatan (Cetakan VI). Jakarta: Penerbit PT. Rineka Cipta.

Nugroho, T. (2012). Patologi kebidanan. Yogyakarta: Nuha Medika, 150-151.

Nurzia, N. (2017). Hubungan Usia dan Paritas Ibu dengan Kejadian Plasenta Previa di Ruang Kebidanan RSUD Raden Mattaher Provinsi Jambi
Tahun 2015. Scientia Journal, 4(4), 310-316.

Oxorn, H., \& Forte, W. R. (2010). Ilmu kebidanan: patologi dan fisiologi persalinan. Penerbit Andi.

Prawirohardjo, S. (2014). Ilmu Kebidanan Sarwono Prawirohardjo. Jakarta: PT Bina Pustaka Sarwono Prawiroharjo.

Prawirohardjo, S. (2010). Ilmu bedah kebidanan. Jakarta: Bina Pustaka.

Rukiyah, A. Y., \& Yulianti, L. (2010). Asuhan kebidanan IV (patologi kebidanan). Jakarta: Trans Info Media.

Runiari, N., Mayuni, I. O., \& Nurkesumasari, N. W. (2013). Usia dan Paritas dengan Plasenta Previa Pada Ibu Bersalin. Jurnal Keperawatan [internet] june.

Taufan, N. (2012). Patologi Kebidanan. Yogyakarta: Nuha Medika. 